\title{
Evaluate the Effect of Intellectual Capital on the Consolidated Performance Evaluation Criteria of Accepted Companies in Tehran's Stock Exchange
}

\author{
Dr. Jamal Bahri Sales \\ Department of Accounting, Islamic Azad University, Orumieh Branch, Orumieh Iran \\ Email: bahrisls.j@gmail.com \\ Yaghoub Pourkarim \\ Department of Accounting, Islamic Azad University, Khosrovshahr Branch, Khosrovshahr Iran. \\ Pourkarim.y@gmail.com \\ Vali Pourkarim \\ Department of Accounting, Islamic Azad University, Heris Branch, Heris Iran \\ Pourkarimv@yahoo.com
}

\author{
Doi:10.5901/mjss.2016.v7n4s2p49
}

\begin{abstract}
The purpose of this study is to evaluate the effect of intellectual capital on the consolidated performance evaluation criteria of accepted companies in Tehran's Stock Exchange during the period of 2008-2014. In this research is calculated intellectual capital by using Palic model(2000), and consolidated performance evaluation criteria of companies by using three consolidated criteria including Tobin's $Q$ ratio,stock price to earnings of per share(P/E) and market value to book value(M/B). To test hypotheses and estimate the effects of variables is used panel data techniques with Ordinary Least Squares(OLS). The results of research show that coefficient of intellectual capital value added has positive effect on the consolidated performance evaluation criteria. Also,for more details was evaluated the effect of subcomponents of intellectual capital on the consolidated performance, that according to the results human capital, physical and financial and structural capital were positive effect on the consolidated performance and the highest influence and effectiveness coefficient is related to human capital and Tobin's $Q$ ratio.
\end{abstract}

Keywords: intellectual capital,Tobin's $Q$ ratio, price to earnings of per share (P/E), market value to book value (M/B).

\section{Introduction}

One of the distinctive features of knowledge-based economy is enormous action of investment in human capital and information and communication technology. Thus in the third millennium in which intellectual capital and not financial capital is a basic infrastructure for mobility and success for company's future in the knowledge economy,it is necessary that key resources and drivers of performance and value in organizations be determined by managers.Because enhancing knowledge and using intellectual capital help companies to be more efficient,more effective, more productive and more innovate.In addition company's competitive position to a greater extent is depend on the strategic management of intellectual capital.Intellectual capital not only is a static intangible asset spontaneity, but also is an ideological process and is considered a means to achieve a goal(Namazi,Ibrahimi,2009). In the meantime the role of intellectual capital is a fact that we cannot be apathetic about it. Negligence in this context can cause irreparable damages on the procedure of capital market indices.Because intellectual capital is shaping economic environment in the countries. Even many scientists believe that main cause of backwardness of some countries is the lack of appropriate intellectual capital for productive activities and not lack of capital resources.

Evaluate the performance of companies is one of the most interesting issues for investors,creditors, managers and government. Practically there are different criteria to evaluate the performance.To select appropriate benchmark,it is necessary to consider the company's strategic goals (Jahankhani \& Zariffard,1995). Over consecutive years many studies have been done to obtain reliable and timely measure to evaluate performance of companies and managers in order to ensure of alignment company's moving with interest of de facto and basis investors to make economic decisions 
of potential investors and creditors. The results of these studies have done to provide four approaches of accounting, economics, integration and financial management regarding performance criteria. In the integrated approach is trying to be used the combine figures of financial statements and market values (a combination of accounting and market information) some scales such as Tobin's $Q$ ratio,stock price to earnings of per share(P/E) and market value to book value (M/B) for analysis (Malekiyan and Asghari,2006).

Due to the fact that on the one hand integrative figures(combined) is one of the best approaches to measurement performance, because in it are used a combination of accounting information (historic values) and market values and also on the other hand the business world today is the field of knowledge-based organizations and in this economy factors such as revenue, profitability and physical assets reflect only a small part of success of organization and real wealth of organizations is absorbed in intangible assets and intellectual capital therefore due to the importance of the issue, in this study has been paid to examine the effect of intellectual capital on the evaluation criteria of integrated performance.

So far several studies are done on examine the effect of intellectual capital on the evaluation criteria of integrated performance.But due to the fact that in none of them evaluation criteria of integrated performance has not been studied into general and together with respect to indicators of Tobin's $Q$ ratio, stock price to earnings of per share (P/E) and market value to book value $(\mathrm{M} / \mathrm{B})$, then in this study has been paid to examine the effect of intellectual capital on the evaluation criteria of integrated performance with respect to all these criteria and using panel data methods simultaneously.

Now according to the items presented above, the questions that this study is seeking to answer them are including:

1. The impact of intellectual capital on the evaluation criteria of integrated performance?

2. Which one of the components of intellectual capital,has the greatest impact on the evaluation criteria of integrated performance?

\section{Literature Review}

Increasing the gap between market value and book value of companies is causes to do several investigations about recognition removed factors from financial statements of companies.Among the factors that effect on the company's value but not provided in the financial statements is the value of intellectual capital (Pourzamani et al, 2012). Intellectual capital is a basic factor to create value in companies and as one of the newfound issues in the accounting issues is still evolution.Intellectual capital is a combine of intangible assets, human assets and infrastructures that makes able the company to fulfill its obligations (abbasi and sedghi, 2010). Intellectual capital has a vast concept and it is difficult to have a precise definition of intellectual capital.But generally it can be said that intellectual capital is divisible into three categories: human capital, structural capital (organizational) and customer capital:

Human capital is the most important asset of an organization and a resource of creativity and innovation. In one organization the assets of tacit knowledge of employees is one of the most vital components that has significant effect on the performance of organization.Also human capital is a combination of knowledge,skill,power of innovation and ability of company's people to perform their duties and including values, culture and company's philosophy.Human capital represents the knowledge of each of staff.Human capital is the starting location of development stages, source of innovation and beginning of insight.In other words human capital is the basic of intellectual capital and the essential element to realization of intellectual capital (Namazi and Ibrahimi,2009).

Adoninson and Malon define structural capital as hardware, software, databases, organizational structure, organization exclusive rights, trademarks and all capabilities of organization that is sponsoring employee productivity.In other words structural capital consists of all non-human knowledge in the organization that includes databases, organizational charts, strategies, procedures, processes guide and everything that its worth for organization is more than its material value. Structure capital is divided into several categories: culture of organization, organizational structure, organizational learning, operational process and information system (Zahedi et al,2007).

Customer capital that as a bridge and catalyst in the activities of intellectual capital is one of the main requirements and determinative the alteration of intellectual capital into market value and consequently business performance. Customer capital is a fundamental component of intellectual capital that value is placed in the marketing and communication channels that the company has with leaders of that industry and trade. The main theme of customer capital is the knowledge used in marketing channels of organization and the relationships with customer while doing business (Namazi \& Ibarahimi, 2009).

Also several researches have defined intellectual capital in various ways. Some definitions of the concept of intellectual capital are:

Pablos knows intellectual capital including all resources of central knowledge that produce value for 
organization, but cannot be enter in financial statements.

- Martinez defines intellectual capital as knowledge, information, intellectual property and experience that can be used in the creation of wealth.

- Mar and Sqwma defined intellectual capital into a group of knowledge assets that are affiliated to an organization and by adding value of organization through determining key beneficiaries, significantly incorporative in improving competitive position of organization.

- According to believe of Lio the intellectual capital is consist of the resources of future profits (value), that is produced by innovation,unique designs of organization or experiences of manpower (Jaafari et al, 2006).

Evaluation of company's performance is one of the most important issues that is consideration for investors, creditors, managers and government.During consecutive years, many studies have been done to obtain reliable and timely measure to evaluate performance of companies and managers in order to ensure alignment of company's move with interests of potential investors and basis to make economic decisions for potential investors and creditors. The results of these studies have done to provide four approaches of accounting, economics, integration and financial management regarding performance criteria:

Accounting approaches: In this approach are used of figures contained in the financial statements such as sale, profit, earning of per share, operating cash flow, return on assets of company, return on equity and et to evaluate the performance.

Integrated approach:In the integrated approach is trying to be used the combine figures of financial statements and market values (a combination of accounting and market information) some scales such as Tobin's Q ratio,stock price to earnings of per share (P/E) and market value to book value(M/B)for analysis (Malekiyan and Asghari, 2006).

Financial management approach:In this approach are used of involved model in financial management such as valuation of investor assets model and risk and return concepts to evaluate and predict.The main emphasis of this approach is to determine excess return of per share (Ansari and Karimi, 2008).

Economic approach:In this approach are used of economic concepts and the performance of business unit are evaluated with emphasis on profitability power of company's assets and according to the return rate and the cost rate of employed capital and economic value added, market value added and adjusted economic value added are in this group (Anvari rostami.et, 2004, 7).

According to some shortcomings that there are in accounting,finance and economic information to evaluate company's performance,integration data (combined)is one of the best approaches to performance measurement, because are used the compilation of accounting data (historic values)and market values (Wester,1994).

\section{Research History}

Pourzamani and et al (2012), paid to examine the effect of the intellectual capitals(human capital,structural capital and financial and physical capital) on the market value(ratio of market value to book value)and financial performance (rate of return on assets) of accepted companies in Tehran's Stock Exchange.Based on the findings the coefficient of intellectual capital efficiency and market value are not significant.This finding of research approve a growing gap between market value and book value of companies. Also the results from obtained tests indicate that the coefficient of intellectual capital efficiency has positive and significant effect on the financial performance of surveyed companies.

Abdullahi (2013), In an article paid to examine the effect of intellectual capital through the valve of human capital on the performance of stock market(through the revenue growth valve) in 21 company of South Africa during the period of 1981-2009. In this study was used combiational data to approach GMM (GMM) and based on the obtained estimates achieved a positive and significant relationship.

Fazel yazdi and et al (2013), paid to examine the performance of artificial neural networks in predicting the efficiency of intellectual capital of accepted companies in Tehran's Stock Exchange within the companies of automotive industry and build their parts sector. The results of estimate showed that artificial neural network model possess of high accuracy in predicting the efficiency of intellectual capital of accepted companies in Tehran's Stock Exchange.

Shakila \& Barajas (2014), paid to examine the creation of value through intellectual capitals in developed markets of Europe and their aim were examine function of companies based on the use of intellectual capital. The results of study shows that the program of Cobb-Douglas framework allowed to design a production function based on the intellectual capitals and the complement of intellectual capital components in the obtained results justified in this study. In this study was observed growing output in scale for intellectual capital in the examined sample.

Dastgir \& et al(2014), paid to examine the effect of intellectual capital on the financial performance (Tobin's Q, ratio of price-to-earnings and growth rate)of accepted companies in Tehran's Stock Exchange and the results show that there 
is significant relationship between intellectual capital and two indicators of financial performance (ratio of price to earnings and growth rate).

Iraji rad \& Eslam dost (2014), paid to measure intellectual capital and examine its relationship with Tobin's Q ratio and beta systematic risk,and the results show that of three components of intellectual capital two components human capital and physical capital with performance criteria of Tobin's Q ratio have positive significant relationship, while structure capital has not significant relationship with this performance criteria.

Biyun \& Dongping (2015), paid to examine the relationship between intellectual capital and firm performance in China's bio-pharmaceutical industry and based on the results the bio-pharmaceutical industry,intellectual capital and firm performance have positive and significant relationship,but association degree of physical capital is weaker.Human capital and structure capital have positive and significant relationship with firm performance.Customer capital and firm performance have positive but non-significant relationship and other components of intellectual capital have impact on each other and effect on the company's performance together.

\section{Hypotheses}

\subsection{Main hypotheses}

1- There is significant relationship between intellectual capital and Tobin's Q ratio.

2- There is significant relationship between intellectual capital and price to earnings of per share (P/E).

3- There is significant relationship between intellectual capital and market value to book value (M/B).

\subsection{Incidental hypotheses}

Considering that intellectual capital has three subcomponents in order to examine the effect of each subcomponent on the value creation,incidental hypotheses is provided below:

1- There is significant relationship between human capital, structural capital and physical and financial capital with Tobin's Q ratio.

2- There is significant relationship between human capital, structural capital and physical and financial capital with price to earnings of per share $(\mathrm{P} / \mathrm{E})$.

3- There is significant relationship between human capital,structural capital and physical and financial capital with market value to book value(M/B).

\section{Variables}

\subsection{Dependent variables}

1- Tobin's $Q$ ratio measurement model:

In this study Tobin's $Q$ ratio will be obtained as follow:

$\mathrm{Qi}=\mathrm{VOCSI}+\mathrm{EMVOPSI}+\mathrm{BVLTI}+\mathrm{BVCLI} / \mathrm{BVTAI}$

In the above model are VOCS:The value of comment stock at the end of year, EMVOPSI:The estimate market value of preferred stock at the end of year, BVCLI: The book value of current liabilities at the end of year, and BVTAl:The book value of total assets at the end of year.

2- Price to earnings of per share $(\mathrm{P} / \mathrm{E})$

3- Market value to book value (M/B)

\subsection{Indepedent variable}

1. Intellectual capital:

To measure intellectual capital is used Pulic model (2000). Pulic model has 5 stages as follow:

The first stage: Determine value added (VA)

VA=OUTPUT-INPUT

OUTPUT: Total earnings from sale of goods and services, and INPUT: Is total cost of materials,components and purchased services.

According to this view every person or group that is affected of events of business unit,must have an interest in the 
business unit. This group of beneficiaries is including shareholders, employees, financial provider, government and society.

Therefore in the performance measurement a criteria such as value added of beneficiary is better than accounting profit that it indicates the return of stockholders (Maditions et al, 2011). Therefore the calculate of value added can be expressed according to following equation:

$\mathrm{VA}=\mathrm{W}+1+\mathrm{T}+\mathrm{NI}$

W: Wage of employees, I:Interest,

$\mathrm{T}$ : Tax and Nl:Is interest after tax.

The second stage:Determine the efficiency of employed capital(physical and financial)

In this model, to provide a complete picture of efficiency of the sources that create value it is necessary to consider efficiency of physical and financial capital,this efficiency is obtained from the following equation:

$\mathrm{VACA}=\mathrm{VA} / \mathrm{CE}$

VACA: The efficiency of employed capital,

CE: Employed capital that is equal to book value of company's total assets minus its intangible assets.

The third stage: Determine the efficiency of human capital

According to this model all staff costs are considered as human capital.

$\mathrm{VAHU}=\mathrm{VA} / \mathrm{HU}$

VAHU: Efficiency of human capital,and HU: The human capital,which is equal to total cost of company's wage.

Fourth stage:Determine efficiency of structural capital

STVA=SC/VA

$\mathrm{SC}=\mathrm{VA}-\mathrm{HU}$

STVA: Efficiency of structural capital,SC:Is the structural capital of company.

Fifth stage: Determine value added coefficient of intellectual capital

VAIC=VACA+VAHU+STVA

Note that in Pulic model, customer capital is not intended (Talebniya et al, 2012).

\section{Society and Sample}

The main purpose of this study is examine the effect of the intellectual capital on the evaluation criteria of integrative performance, so present study in terms of purpose is component of applied researches and in terms of methodology is component of causal after incidence of correlation researches. Statistical population of this study is including all accepted companies in Tehran's Stock Exchange. To select the sample is selected systematic deletion method, and following conditions are considered:

1) Fiscal year has been ending in March,and it hasn't been changed during the examined period.

2) Companies must don't have transactional interruption more than three consecutive months.

3) The required data for the study must be presented during the period fully.

4) Companies must don't have negative shareholders' equity and don't be disadvantageous.

5) Be accepted in Tehran's Stock Exchange before 1387.

6) Don't be component of investment (Holding)and intermediation companies.

After applying the above conditions 64 companies are in the sample of study,and the period of study is 2008-2014 and is consist of 448 year-company totally.

\section{Research Method}

In order to collect information on specifying issue literature of study are used library and documentary studies method,and to obtain required information to process hypotheses of study are used the available information in software of Rahavarde no's company and examine the financial statements of accepted companies in Tehran's Stock Exchange by visiting official website of Tehran's Stock Exchange.In this stage,after collecting statistical data to conclusion and required calculations is used Excel software, and to test the hupotheses is used panel data techniques to approach Ordinary Least Squares method by EVIEWS software.

Also the examined models of present article are introduced by inspired of Pulic model and Trisnowati \& Fadeh article (2014):

$$
\begin{aligned}
& Q_{i t}=\beta_{0}+\beta_{1} V_{A I C} C_{i t}+\varepsilon_{i t} \\
& P / E_{i t}=\beta_{0}+\beta_{1} V_{I I} C_{i t}+\varepsilon_{i t}
\end{aligned}
$$


$M / B_{i t}=\beta_{0}+\beta_{1} V A I C_{i t}+\varepsilon_{i t}$

$Q_{i t}=\beta_{0}+\beta_{1} H C_{i t}+\beta_{2} S C_{i t}+\beta_{3} C C_{i t}+\varepsilon_{i t}$

$P / E_{i t}=\beta_{0}+\beta_{1} H C_{i t}+\beta_{2} S C_{i t}+\beta_{3} C C_{i t}+\varepsilon_{i t}$

$M / B_{i t}=\beta_{0}+\beta_{1} H C_{i t}+\beta_{2} S C_{i t}+\beta_{3} C C_{i t}+\varepsilon_{i t}$

In the above models, Q: Indicates Tobin's Q, P/E: Indicates price to earnings of per share, M/B:Indicates market value to book value, VAIC: Indicates value added coefficient of intellectual capital, HC: Indicates human capital, SC: Indicates structural capital, CC: Indicates physical and financial capital,and $\varepsilon$ :Indicates the random error.

\section{Analysis}

\subsection{Examine normality of variables}

To examine normality of variables was used Kolmogrof-Smirnof test.As the results of table 1, achieved significant levels (greater than 5\%) indicate that distribution amounts of dependent variables are normal, and thus we can use the regression equations (1) till (6) in order to determine intellectual capital and evaluate criteria of integrative performance.

Table 1. The results of determine the normal distribution test of dependent variable amounts

\begin{tabular}{cc}
\hline \hline Variable & significant level \\
\hline $\mathrm{Q}$ & $0 / 0758$ \\
\hline $\mathrm{P} / \mathrm{E}$ & $0 / 0632$ \\
\hline $\mathrm{M} / \mathrm{B}$ & 0.0873 \\
\hline \hline
\end{tabular}

Source: Findings of Research

\subsection{Examine the linearity between variables}

To examine the linearity between independent and dependent variables we have formed the diagonal matrix.Since the results of table(2)and(3) suggest,because all elements outside main diagonal of matrix are lower than $0 / 9$, so to estimate the models there isn't linearity relationship, and so we paid to estimate the models in the following.

Table 2.The results of the linearity relationship between independent and dependent variables in equations (1) till (3):

\begin{tabular}{ccc}
\hline \hline & $(1)$ & \\
\hline Variable & $\mathrm{Q}$ & VAIC \\
\hline $\mathrm{Q}$ & $1 / 0000$ & $0 / 0661$ \\
\hline VAIC & $0 / 0661$ & $1 / 0000$ \\
\hline & $(2)$ & \\
\hline Variable & $\mathrm{P} / \mathrm{E}$ & VAIC \\
\hline P/E & $1 / 0000$ & $0 / 0178$ \\
\hline VAIC & $0 / 0178$ & $1 / 0000$ \\
\hline Variable & $(3)$ & \\
\hline M/B & $\mathrm{M} / \mathrm{B}$ & VAIC \\
\hline VAIC & $1 / 0000$ & $0 / 0660$ \\
\hline \hline
\end{tabular}

Source: Findings of Research

Table 3. The results of the linearity relationship between independent and dependent variables in equations (4) till (6)

\begin{tabular}{|c|c|c|c|c|}
\hline \multicolumn{5}{|c|}{ (4) } \\
\hline Variable & $Q$ & SC & $\mathrm{HC}$ & $\mathrm{CC}$ \\
\hline $\mathrm{Q}$ & $1 / 0000$ & 0/0101 & $0 / 0666$ & $0 / 3371$ \\
\hline $\mathrm{SC}$ & 0/0101 & $1 / 0000$ & $0 / 0025$ & $0 / 0488$ \\
\hline
\end{tabular}




\begin{tabular}{|c|c|c|c|c|}
\hline $\mathrm{HC}$ & $0 / 0666$ & $0 / 0025$ & $1 / 0000$ & $0 / 0695$ \\
\hline $\mathrm{CC}$ & $0 / 3371$ & 0/0488 & 0/0695 & $1 / 0000$ \\
\hline \multicolumn{5}{|c|}{ (5) } \\
\hline Variable & $P / E$ & $\mathrm{SC}$ & $\mathrm{HC}$ & $\mathrm{CC}$ \\
\hline $\mathrm{P} / \mathrm{E}$ & $1 / 0000$ & $0 / 0464$ & 0/0178 & $0 / 0068$ \\
\hline $\mathrm{SC}$ & $0 / 0464$ & $1 / 0000$ & $0 / 0695$ & $0 / 0488$ \\
\hline $\mathrm{HC}$ & $0 / 0178$ & $0 / 0695$ & $1 / 0000$ & $0 / 0025$ \\
\hline $\mathrm{CC}$ & $0 / 0068$ & $0 / 0488$ & $0 / 0025$ & $1 / 0000$ \\
\hline \multicolumn{5}{|c|}{ (6) } \\
\hline Variable & $M / B$ & SC & $\mathrm{HC}$ & $\mathrm{CC}$ \\
\hline $\mathrm{M} / \mathrm{B}$ & $1 / 0000$ & $0 / 3371$ & $0 / 3371$ & $0 / 0101$ \\
\hline SC & $0 / 3371$ & $1 / 0000$ & $0 / 0695$ & $0 / 0488$ \\
\hline $\mathrm{HC}$ & $0 / 3371$ & 0/0695 & $1 / 0000$ & $0 / 0025$ \\
\hline $\mathrm{CC}$ & 0/0101 & $0 / 0488$ & $0 / 0025$ & $1 / 0000$ \\
\hline
\end{tabular}

Source: Findings of Research

\subsection{Estimating the effects}

After normality and linearity review, it is necessary to be done the relevant diagnostic tests to determine kind of estimated model.In order to ensure the significance of the group of companies in the sample was used significance test of the group. For this purpose used the F statistic.If the calculated F-statistic is greater than F in the table,the Ho's theory based on equality the intercepts cannot be accepted and it must be considered several intercepts in the estimate of model.So it can be used panel method in order to estimate. Now to answer whether the difference in the intercept of sectional units acts constantly or random functions can more clearly express difference between units is used Hausman test.In Hausman test $\mathrm{H}_{0}$ hepotheses based on the compatibility of random effect estimates is tested versus $\mathrm{H}_{1}$ hypotheses based on incompatibility of random effect.If $H_{0}$ hypotheses isn't accepted should be used the fix effects estimation method in order to estimate. Otherwise is done the random effects estimation method.In the following for each of the above estimates has been explained in detail the relevant diagnostic tests.

\subsubsection{The results of estimate (1) till (3) models}

Based on the results of table (4)in all surveyed companies $\mathrm{H}^{0}$ hypothesis based on the equality of intercepts is rejected and should be considered different intercepts in estimation. Thus in order to estimate can be used panel method.

Table 4.The results of $\mathrm{F}$ test for equations (1) till (3)

\begin{tabular}{lcccc}
\hline \hline Effects Test & & Statistic & d. f. & Prob \\
\hline Cross -Section F & $(1)$ & & & \\
\hline Cross-section Chi-square & & $20 / 8046$ & $(63,414)$ & $0 / 0000$ \\
\hline & $(2)$ & $593 / 3484$ & 63 & $0 / 0000$ \\
\hline Cross -Section F & & $23 / 9253$ & $(63,414)$ & $0 / 0000$ \\
\hline Cross-section Chi-square & & $593 / 2836$ & 63 & $0 / 0000$ \\
\hline & $(3)$ & & & \\
\hline Cross -Section F & & $20 / 8426$ & $(63,414)$ & $0 / 0000$ \\
\hline Cross-section Chi-square & & $593 / 9703$ & 63 & $0 / 0000$ \\
\hline \hline
\end{tabular}

Source: Findings of Research

However to determine the type of estimation method in terms of fixed or random effects shoud be examined Hausman test.Based on the results of Hausman test in the table (5) $\mathrm{H}_{0}$ hypotheses based on the compatibility of random effect estimations in all the above companies isn't rejected and estimate should be done with random effects method. 
Table 5.The results of Hausman test for equations (1)till (3)

\begin{tabular}{lccc}
\hline \hline Effects Test & Statistic & d. f. & Prob \\
\hline & $(1)$ & & \\
\hline Cross-section random & $2 / 1254$ & 1 & $0 / 1449$ \\
\hline & $(2)$ & & \\
\hline Cross-section random & $2 / 1126$ & 1 & $0 / 1356$ \\
\hline Cross-section random & $(3)$ & & \\
\hline \hline
\end{tabular}

\section{Source: Findings of Research}

Finally the estimation results of models (1) till (3) is provided in table (6) and show that the value added coefficient of intellectual capital has positive effect on the Tobin's Q ratio,the ratio of stock price to earnings of per share and the ratio of market value to book value and is significant at $1 \%$ level.But in the meantime the impressionable coefficient of Tobin's $\mathrm{Q}$ from value added coefficient of intellectual capital are more than two other criteria. Therefore the first, second and third main hypothesis of this study are confirmed.

Table 6.The results of estimate (1) till (3) models

\begin{tabular}{cccc}
\hline \hline Variable & Coefficient & t-Statistic & Prob \\
\hline \multicolumn{5}{c}{$(1)$} & & \\
\hline C & $1 / 3356$ & $23 / 2506$ & $0 / 0000$ \\
\hline VAIC & $4 / 5567$ & $2 / 1649$ & $0 / 0003$ \\
\hline \multicolumn{5}{c}{$(2)$} & & \\
\hline VAIC & $1 / 4023$ & $44 / 2587$ & $0 / 0000$ \\
\hline \multicolumn{5}{c}{$0 / 2689$} & $(3)$ & & $0 / 0041$ \\
\hline VAIC & $1 / 3756$ & $23 / 2250$ & $0 / 0000$ \\
\hline \hline
\end{tabular}

Source: Findings of Research

\subsubsection{The results of estimate (4) till (6) models}

Based on the results of table (7) in all surveyed companies $\mathrm{HO}$ hypothesis based on the equality of intercepts is rejected and should be considered different intercepts in estimation. Thus in order to estimate can be used panel method.

Table 7. The results of $F$ test for equations (4)till(6)

\begin{tabular}{|c|c|c|c|}
\hline Effects Test & Statistic & d. f. & Prob \\
\hline \multicolumn{4}{|c|}{ (4) } \\
\hline Cross -Section F & $17 / 5596$ & $(63,412)$ & $0 / 0000$ \\
\hline Cross-section Chi-square & $539 / 3298$ & 63 & $0 / 0000$ \\
\hline \multicolumn{4}{|c|}{ (5) } \\
\hline Cross -Section F & $16 / 2316$ & $(63,412)$ & $0 / 0000$ \\
\hline Cross-section Chi-square & $539 / 4327$ & 63 & $0 / 0000$ \\
\hline \multicolumn{4}{|c|}{ (6) } \\
\hline Cross -Section F & $17 / 5750$ & $(63,412)$ & $0 / 0000$ \\
\hline Cross-section Chi-square & $539 / 6105$ & 63 & $0 / 0000$ \\
\hline
\end{tabular}

Source: Findings of Research

However to determine the type of estimation method in terms of fixed or random effects shoud be examined Hausman test.Based on the results of Hausman test in the table (8) $\mathrm{H}_{0}$ hypotheses based on the compatibility of random effect 
estimations in all the above companies isn't rejected and estimate should be done with random effects method.

Table 8. The results of Hausman test for equations (4)till(6)

\begin{tabular}{|c|c|c|c|}
\hline Effects Test & SStatistic & d. f. & Prob \\
\hline \multicolumn{4}{|c|}{ (4) } \\
\hline Cross-section random & $9 / 6256$ & 3 & $0 / 1220$ \\
\hline \multicolumn{4}{|c|}{ (5) } \\
\hline Cross-section random & $10 / 8325$ & 3 & $0 / 1323$ \\
\hline \multicolumn{4}{|c|}{ (6) } \\
\hline Cross-section random & $9 / 8257$ & 3 & $0 / 1201$ \\
\hline
\end{tabular}

\section{Source: Findings of Research}

Finally the estimation results of models (4)till(6) is provided in table (6) and show that the value added coefficient of intellectual capital has positive effect on the Tobin's Q ratio,the ratio of stock price to earnings of per share and the ratio of market value to book value and is significant respectively at $1 \%$ and $5 \%$ and $1 \%$ levels and the impressionable coefficient of intellectual capital on Tobin's $Q$ ratio are more than two other criteria.On the other hand the impressionable coefficient of intellectual capital is more than structural,physical and financial capitals.Also structural capital has positive effect on the Tobin's Q ratio,the ratio of stock price to earnings of per share and the ratio of market value to book value and is significant respectively at $1 \%$ and $5 \%$ and $1 \%$ levels.Finally physical and financial capitals have positive effect on the Tobin's Q ratio,the ratio of stock price to earnings of per share and the ratio of market value to book value and is significant respectively at $1 \%$ and $5 \%$ and $1 \%$ levels. Therefore the first,second and third incidental hypothesis of this study are confirmed.

Table 9. The results of estimate (4) till (6) models

\begin{tabular}{|c|c|c|c|}
\hline Variable & Coefficient & t-Statistic & Prob \\
\hline \multicolumn{4}{|c|}{ (4) } \\
\hline $\mathrm{C}$ & $1 / 4236$ & $90 / 1536$ & $0 / 0000$ \\
\hline $\mathrm{CC}$ & $0 / 1789$ & $3 / 9226$ & $0 / 0001$ \\
\hline $\mathrm{HC}$ & $5 / 6689$ & $2 / 1244$ & $0 / 0341$ \\
\hline $\mathrm{SC}$ & $0 / 0214$ & $1 / 7345$ & $0 / 0439$ \\
\hline \multicolumn{4}{|c|}{ (5) } \\
\hline C & $1 / 4023$ & $0 / 9025$ & $0 / 0000$ \\
\hline CC & $0 / 2678$ & $1 / 7762$ & $0 / 0466$ \\
\hline $\mathrm{HC}$ & $4 / 1657$ & $6 / 0331$ & $0 / 0000$ \\
\hline $\mathrm{SC}$ & $2 / 9334$ & $1 / 9561$ & $0 / 0004$ \\
\hline \multicolumn{4}{|c|}{ (6) } \\
\hline C & $2 / 2367$ & $80 / 1426$ & $0 / 0000$ \\
\hline $\mathrm{CC}$ & $0 / 1685$ & $2 / 6113$ & $0 / 0005$ \\
\hline $\mathrm{HC}$ & $2 / 6236$ & $2 / 8621$ & $0 / 0001$ \\
\hline $\mathrm{SC}$ & $0 / 1785$ & $4 / 8152$ & 0/0001 \\
\hline
\end{tabular}

Source: Findings of research

\section{Discussion and Conclusion}

The purpose of this artical is to evaluate the effect of intellectual capital on the consolidated performance evaluation criteria and the results of the estimates indicate that the value added coefficient of intellectual capital has positive effect on the Tobin's Q ratio,the ratio of stock price to earnings of per share.In order to more accurate examines the effect of the subcomponents of intellectual capital (human capital,physical and financial capital and structural capital) were examined on the integrative performance of evaluation criteria that based on the results human capital, physical and financial capital and structural capital have positive effect on the integrative performance of evaluation criteria, and the highest coefficient of effectiveness and impressional is related to human capital and Tobin's $Q$ ratio. 
The results indicate that findings of research are compatible with findings of foreign studies like El Vi \&Han (2015), Abdullahi (2013). Also the results indicate that findings of research are compatible with the majority of findings of internal studies, and the differences can also be seen.For examole in the findings research of Dastgir et al(1393), the relationship between intellectual capital and ratio of price to earnings is positive and significant, but there isn't a significant relationship between intellectual capital and Tobin's Q.Also in the research of Iraji rad and Islam dost (1393) there is positive and significant relationship between intellectual capital (human and physical) and Tobin's Q, but there isn't a significant relationship between intellectual capital (structural capital) and Tobin's Q. The offers of the research findings are including:

1- It is suggested that Tehran's Stock Exchange observe seminars and training classes in this context.Also brokers express the necessary subjects about the situation of intellectual capital in the company and its impact on the competitiveness and profitability when they providing consulting services.

2- According to the findings of research and the relationship between intellectual capital and value creation criteria it can be offered to investors and other users of information that in order to make investment decisions give high importance to integrative criteria including Tobin's $Q$ ratio, stock price to earnings of per share (P/E) and market value to book value (M/B).

\section{References}

Abbasi, Ibrahim and Sedghi, Aman galdi. (2010). The effect of the efficiency of intellectual capital elements on the financial performance of companies in Tehran's Stock Exchange.Review of accounting and auditing. No 6.PP 74-57.

Abdullahi, D. (2013). Effects of financial liberalization on financial market development and economic performance of the SSA region: An empirical assessment. Economic Modelling. NO. 30. PP. 261-273.

Ansari, Abdulmahdi and Karimi, Mohsen. (2008).Examine the financial criteria of management performance evaluate in the create value for shareholders with emphasis on economic criteria.Accountant.No 200.PP 11-3.

Anvari Rostami, Aliasgar, Tehrani, Reza and Seraji, Hasan. (2004). The relationship between economic value,earnings before interest and tax and cash flows of operating activities with stock market value of accepted companies in Tehran's Stock Exchange. Accounting and auditing reviews. No3.PP21-3.

Biyun, L. \& Dongping, H. (2015). The Relationship between Intellectual Capital and Corporate Performance in Chinese Biopharmaceutical Industry. SHS Web of Conferences.

Dastgir, Mohsen, Arab salehi, Mehdi, Amin Jaafari, Raziyeh and Akhlaghi, Hasanali. (2013). The effect of intellectual capital on the financial performance of the company. Researchs in financial accounting and auditing. No 21.PP 1-36.

Fazel yazdi, Ali, Taghizade mehrjardi, Rohollah and Tahari mehrjardi, Mohammadhosein. (2013). The performance of drtificial neural networks in predicting the efficiency of intellectual capital in accepted companies in Tehran's Stock Exchange (Case study:the companies of manufacturing automotive sector). Journal of Financial Engineering and Management of Stock.No 16.PP 127-153.

Iraji rad, Arsalan and Islam dost, Maasomeh (2014), Measuring intellectual capital and examining its relationship with Tobin's Q and beta systematic risk. Quarterly asset management and financing. No 4.PP 97-110.

Jaafari, Mostafa, Rezai nour, Jalal and Hosnavi, Reza. (1995), Revision the measurement models of intellectual capital: A holistic approach, The fourth International Conference on Management, Management and Economics Faculty of Sharif university.

Jahankhani, Ali, and Zarif fard, Ahmad. (1995). Do the managers and shareholders have used appropriate criteria to measure value of the company ? Scientific and Research Journal of Financial Researchs. No 7 and 8.PP 41-66.

Pourzamani, Zahra, Jahanshad, Azita and Mahmodabadi, Ali. (2012). The effect of intellectual capital on the market value and financial performance. Accounting and auditing reviews.No 2.PP 17-30.

Shakila, E. \& Barajas, A. (2014). Value creation through intellectual capital in developed European markets. Journal of Economic Studies. No. 41. PP. 272-291.

Talebniya, Ghodratollah, Khan Hoseini, Davood, Maazar Mollaghasem, Elahe and Niko Nesbati, Mohammad. (2012). The effect of intellectual capital on the market value and financial performance of accepted companies of cement industry in Tehran's Stock Exchange.Empirical Research in Accounting. No 5.PP 51-66.

Malekiyan, Esfandiyar and Asgari, Jaafar. (2006).Study the relationship between economic value added and retun on assets rate in order to evaluate the performance of accepted companies in Iran's Stock Exchange,Exchange,No 54-55.PP 24-33.

Namazi, Mohammad and Ibrahimi, Shahla. (2009). The effect of intellectual capital on the future and current financial performance of accepted companies of Tehran's Stock Exchange. Accounting Research.No 4.PP 1-23.

Wester, R. (1994). Corporate Finance. PP. 45-46.

Zahedi, Seyyed Mohammad and Lotfizade, Fereshteh. (2007). The intellectual capital measurement dimensions and models, Management Studies Journal.No 55.PP39-64. 